\title{
Social Intelligence and Its Relation with the Pattern of Social Relationships (Cooperation, Competitive) of the Average Diploma Students in Jordan
}

\author{
Dr. Etaf M. Al-Kfaween \\ Department of psychology, Faculty of education \\ Tafila technical university, Tafila, Jordan \\ E-mail: EtafK2016@Gmail.com
}

Received: June 7, 2019 Accepted: August 6, 2019 Published: August 6, 2019

doi:10.5296/jse.v9i3.15094ＵRL: https://doi.org/10.5296/jse.v9i3.15094

\begin{abstract}
The current study aimed to recognise the level of social intelligence and its relationship with the patterns of social interactions (cooperating and competition) and knowing the differences between the sample individuals according to the employment statues and residence (city or village). A random of sample of diploma students was selected in Tafila Technical University, it reached (189) student, and the scale of social intelligence, and the scale of social relationships (cooperation and competition).

The results indicated that the level of social intelligence was average and there was a positive connection between social intelligence and the pattern of cooperation. The employed students have more interest to cooperate, and the differences between city and village students are statistically indicated. The study recommended to reconsider the strategies used with the students in teaching situations where cooperate encouraging strategies are used.
\end{abstract}

Keywords: Social Intelligence, Cooperation, Competition, Average diploma students 


\section{Introduction:}

Social Intelligence had a great interest from researchers which has a part in enhancing the performance of the individual in different social situations. Of which it plays a vital part in the students' learning experiences which the student interacts with the tutor and gets feedback and support from (Arghode, 2014).

The individual gains basic character skills from Social Intelligence by self-conscious, stress and anger management, and of the ability to solve problems that encounter them, therefore, making a good decision (Goleman, 2006).

Social intelligence is defined as a group of skills that give the individual a chance to deal with social situations that encounters the individual skillfully, as well as the ability to understand others. (Lau, 2016) As the social intelligence is a learned skill gained from the surrounding environment and of social situations that the individual live throughout different age phases. (Ali, Ahmad\&Khan, 2019)

Thorndike used social intelligence when discussing abstract, mechanical and social intelligence, and pointed out that the social intelligence gives the ability to understand others and deals with social situation in a good manner (Cantor\& Kihlstrom, 2000).

As the social intelligence points out social skills competence and emotional intelligence, the individual that has social intelligence has the ability to choose the right behavior that helps them to reach their goals of which they hoped for, as some scientist thought of social intelligence to be social competence. And pointed that it is created of social conscious and sensing the opposite individual. And social competence means selecting the right behavior when dealing with the opposite individual. (Eshghi, Etemadi, Mardani, Fanaei \& Hosaini, 2013)

It is a storage of knowledge that has a direct connection to the individual's social life, and the individual's self-concept of others and the situations that encounters them as well as the ability to manage strong feeling are created. (Wyer\& Srul, 1989)

the ability to control people when it comes to emotions, motives, ideas, intentions, and understanding of an individual's emotions, behaviours, and ideas as well as the ability to recognise an individual from the body and encounter language.

There are requirements for social intelligence that is sensitive of others behaviour and ability to recognise the mood status that an individual lives as well as the ability to be creative. (Weis, 2008)

The individual who has a high level of social intelligence that is able to attract others to and feels respect, love, competence, and recognition from others, but the individual who has a low level of social intelligence might feel guilty, angry and low self-esteem and has a negative behaviour towards others. (Albrecht, 2006)

When the level of social intelligence is higher there is an interest of the individual themselves in using right solutions in dealing with the issues as there is a positive connection between 
social intelligence and empathy with others, and there is a negative connection between social intelligence and aggressive behavior. (Bjorkqvist, Osterman \& Kaukiainen, 2000). There is a connection between social intelligence and optimism because the achievement of an optimist individual is better than a pessimist individual (Wyer \& Srull, 1989)

As the individual gains the social intelligence from experiences in interacting with others. (Hunt,2019), it contributes in helping the individual with adapting in the environment that they live in and enjoys the required tasks of which they have to finish. (Bodnar \& Bodnar, 2018)

The individual that has social intelligence has the ability to control their emotions towards others, and is able to solve the problems in social situations. Social intelligence includes different aspects:

*social skills: which are the abilities the individual has in different situations.

*data processing: it points to the individual's ability in dealing with situations that is a source to self-hurt for the individual like sadness and anger.

*social conscious: includes the individual's ability in understanding others.

*social desire: points to controlling emotions and managing them in life experience. (Ebrahimpoor, Zahed\& Elyasi, 2013)

Social intelligence is gained through the surrounding environment therefore there are defined behaviours in the culture which grows social intelligence skills of the individuals and another culture that aims in reducing the level of social intelligence of the individuals,(Baggiyan,Pankajam,2017) and when the cultural intelligence was taught to university students in our Jordanian environments the studies showed that the level of cultural intelligence was average and that is not effected by the student's residence. (Amomani \& Atoum, 2016)

The social intelligence plays a vital part in having leadership skills while interacting in social situations. (Reiter\&Rickers, 2001) As the nature of the relationship between the individuals plays a part, the students that have a preference in cooperating excel the students that has a preference in competing in problem solving. (Qin, Johnson\& Johnson, 1995) As the social anxiety forces people to read the social interaction as a kind of competitive struggles therefore social anxiety is connected with competitive goals and the aggressive behaviour during interactions. (Tone, Nahmias \& Baxeman, 2018)

In the environment of the city and the environment of the village, the results indicate that there is a low level of cooperate behaviour with a similar rise in competitive behaviour levels of village and city citizens.

(Garcia, Rivera\& Greenfield, 2015)

Therefore, social intelligence has a connection with the social interaction and the kind of strategies that the individual uses to encounter challenges and difficulties in social situations, as it lets them choose the right decisions. As a result the students have patterns of social 
interactions, cooperating, and competition like this study. That is why this study is made to know the levels of social intelligence and its relationship with the known social interaction pattern of the students in cooperation and competition in Jordan.

\section{Previous Studies}

Won, Heo\&, Choi (2018) studied the relationship between social and emotional intelligence and flexibility of university students on a sample of (250) students. The results indicated that there is a positive relationship between emotional and social intelligence and flexibility.

Malik, Siddique \&Hussain (2018) the study aimed to know how to develop social intelligence through stages of university studies, the sample is (560) students. The results showed that the evolution level of social intelligence throughout the years is with statistical indications. The social intelligence of males is higher than females but there are some different aspects according to city and village environments.

Rezaei, Khosr \& Bahadori (2018) studied the relationship between optimism and social intelligence, the sample consisted of (332) human sciences faculty students, of which (213) females and 119 males. The results indicated that there is a positive relationship between data processing, social skills, optimism, life satisfaction, and social intelligence skills. Social intelligence increases life satisfaction of university students.

Baggiyan \& Pankajam (2017) studied the relationship between social intelligence and academic GPA on a sample of 300 students and the results indicates a positive relationship between social intelligence and academic GPA.

Buzdar, Waqas, Mhonsin \&Nadeem (2016) studied the relationship between social intelligence and religious guides of university students in Pakistan, the sample is (500) students. The results indicated that there is a relationship between social intelligence and religious guidelines of students.

Terwase, Ibaishwa \& Eneemari (2016) studied the parental formation and students gender in predicting the social intelligence on (294) students of which (151) males and (143) females. The results indicated that the easy parental formation affects positively on raising social intelligence.

Ganaic \& Mudasir (2015) study was interested in social intelligence and academic GPA of a sample of students (275) of which, (150) science students and (125) social sciences students. Patience, cooperation, trust, and social environment sensitivity, courtesy, and humour. Results indicated that the social science students had higher social intelligence levels than science students, but the science students had higher GPA.

Saxena\& Jain (2013) studied the social intelligence and its relationship with the gender of university students, the study consisted of( 120) students of which( 60) males and( 60) females, the results pointed out that the females had higher social intelligence levels than males, and the art students had higher levels of social intelligence than other specialties. 


\section{Macrothink}

Gnanadevan (2011) studied the levels of social intelligence and its relationship with social level and income level, on a sample of (400) students, there are some differences in social intelligence levels according to the social and income levels as well as the education level of the mother, there where statistical indications with great differences among students. There weren't any differences according to the father's education levels or the mother's profession.

Hooda, Sharm\& Yadava (2009) The Study's goal was to know the relationship between social intelligence and psychological health for a sample of students of 300 of which 170 males and 130 females, and the scale of social intelligence and satisfaction of life and happiness were used. And the results indicated that there is a positive connection between social intelligence and psychological health by life satisfaction and happiness.

Roseth, Johnson\& Johnson (2008) studied the GPA, pier relationship, cooperation, and competition on a sample of (1700) teenager from 11 countries and 4 nationalities. The results indicated that the GPA and social relationships where positively connected with cooperation and competition.

Kolawole (2008) studied the effect of cooperative and competitive learning on the academic performance on a sample of high school students in Nigeria where the sample is (400) students of which (240) males and (160) females, the results indicated that the cooperative learning method had a larger effect on academic performance than the competitive method.

Samee (2007) this study aimed on knowing the levels of social intelligence and aggressive behaviour, and the relationship between them among a sample of (84) students, the results indicated that the level of social intelligence is average and that there is a negative relationship between social intelligence and aggressive behavior.

Vyrostj \& Kyselova (2006) studied the relationship between social intelligence, wisdom, values, and characteristics, of a sample of university students that consists of (44) students. The results pointed that there is a positive relationship between social intelligence in data processing aspects in self-conscious and wise knowledge.

Humphrey, Johnson \&Johnson (1982) studied the effect of cooperation and competitive on the students' GPA as well as their accomplishments on sample of (44) students. The results indicated that there is a cooperative relationship which had a great role in mastering and memorizing the educational subject, more than the competitive relationship or individual work.

Andrew \& Johnson (1979) study was interested in knowing the differences in cooperation and competitiveness of a sample of (2400) students, of which the results indicated that females are more drawn to cooperation and males to competitiveness.

\section{Study Importance}

-The study importance is shown in its role of highlighting social intelligence and its importance in succeeding the individual's daily life and helping them in adapting. 


\section{Macrothink}

-The importance emerges in the pattern of social relationships (cooperation, competitiveness) in affecting the individual's choice of the appropriate behaviour at the right social situations.

The results of this important study and its possible use in future studies.

\section{Study purpose}

- Knowing the level of social intelligence among average diploma students in Jordan.

- Knowing the nature of relationship between social intelligence and the social relationship pattern (cooperative, competitive) of average diploma students in Jordan.

- Knowing the nature of the relationship between social intelligence and student's work and here home place among average diploma students in Jordan.

\section{Study Questions}

1What is the level of social intelligence of average diploma student in Jordan?

2Are there any differences of statistical indications among average diploma students in social relationships (competitive, cooperative) according to the variable of student's Home place?

3 Are there differences with statistical indications among average diploma students in social relationship (competitive, cooperative) according to the variable of student's Employment?

4Is there a connection of statistical indication between social Intelligence and student's Home place?

5Is there a connection of statistical indication between social Intelligence and student's employment?

6Is there a statistical connection between social intelligence and the social pattern (cooperative, competitive)?

\section{Method}

The study society is of all average diploma students in Tafila Technical University in Jordan, and a random selection of (189) student of all majors were selected.

\subsection{Study Design}

This study is considered as a descriptive study.

\subsection{Study Statistics}

-To answer the study related questions and calculating the means and standards deviation

-To know the differences among the study variables and use the T test.

To know the nature of the relationship between social intelligence and social relations and finding the relation factor. 


\section{1) Macrothink}

\subsection{Study society and sample}

The society of the study consisted of all the average diploma students and registered in the second semester 2019-2018 in the middle technical college (the humanitarian sciences, engineering and science faculties), that reached (543) students. The study sample was tested randomly of which it reached (189) students, the percentage of the sample according to the society is:

\begin{tabular}{lll}
\hline Study society & Study sample & percentage \\
\hline 543 & 189 & $34.8 \%$ \\
\hline
\end{tabular}

\subsection{Study Scale:}

Social intelligence scale was used (Abu Amsha, 2013) after modifying it to suit the Jordanian environment. The scale in its final shape consisted of( 37) paragraph that measures four dimensions, communicate with others, social interaction, respond to others, and influence in social attitudes. Each paragraph has five option (always, frequently, sometimes, rarely, never) and the high grade of the scale indicates high social intelligence.

The second scale

The social pattern scale (competitiveness and cooperation) (Al-kfaween, 1994) consists of 22 paragraphs each paragraph has a relationship with the pattern of social relationships (cooperative, competition) and each paragraph has five options (always, frequently, sometimes, rarely, never)

The third scale consists of two questions, the first is about the accommodation of the student (city or village), and the second is whether the student works or not.

\section{Results}

In purpose to know the levels of social intelligence was calculated the mean and stand deviation grades of the students in the sample as shown in table 1.

Table 1. Means and standard deviation for the grads of the students in the grads of the students in the sample on the scale of SI

\begin{tabular}{llll}
\hline Variable & $\mathrm{N}$ & Mean & Std Deviation \\
\hline Social Intelligence & 189 & 3.170 & .185 \\
\hline
\end{tabular}

To find the level of each dimension of the social intelligence, the mean and stand deviation grades was collected, which Table 2 shows. 
Table 2. Means and stand deviation of the social intelligence dimensions of the study sample.

\begin{tabular}{llll}
\hline Dimensions & $\mathrm{N}$ & Mean & $\begin{array}{l}\text { Std Deviation } \\
\text { Communicate with }\end{array}$ \\
$\begin{array}{l}\text { Others } \\
\text { Social Interaction }\end{array}$ & 189 & 3.134 & .340 \\
Respond to others & 189 & 3.160 & .310 \\
Influence and & 189 & 3.103 & .313 \\
Influence in social & & 3.30 & .334 \\
attitudes & & & \\
\hline
\end{tabular}

To find whether there are any differences in the social relationship between cooperation and competition students of the study sample and home place, the means and stand deviation where collected, in addition to finding the known differences, the $\mathrm{T}$ test was conducted which the Table 3 shows.

Table 3. The results of the $\mathrm{T}$ test for the social relation ship cooperation and competition students of the sample in the light home place variable.

\begin{tabular}{lllllll}
\hline $\begin{array}{l}\text { Social } \\
\text { relationship }\end{array}$ & $\begin{array}{l}\text { Home } \\
\text { place }\end{array}$ & Mean & $\begin{array}{l}\text { Std } \\
\text { Deviation }\end{array}$ & T & df & Sig \\
\hline Cooperation & City & 3.17 & .37 & 1.05 & 187 & .294 \\
& Vallije & 3.09 & .45 & & & \\
Competitive & City & 3.63 & .326 & 1.25 & 187 & .213 \\
& Vallije & 3.54 & .480 & & & \\
\hline
\end{tabular}

To find whether there are any differences in the social relationship between cooperation and competition students of the study sample and student work the means and stand deviation where collected, in addition to finding the known differences, the $\mathrm{T}$ test was conducted which the Table 4 shows.

Table 4. The results of the $\mathrm{T}$ test for the social relation ship cooperation and competition students of the sample in the light student work variable.

\begin{tabular}{lllllll}
\hline $\begin{array}{l}\text { Social } \\
\text { relationship }\end{array}$ & Employment & Mean & $\begin{array}{l}\text { Std } \\
\text { Deviation }\end{array}$ & T & df & Sig \\
\hline Cooperation & Work & 3.23 & .300 & 3.73 & 187 & .000 \\
& Not work & 3.00 & .516 & & & \\
Competitive & Work & 3.41 & .338 & 5.00 & 187 & .000 \\
& Not work & 3.71 & .475 & & & \\
\hline
\end{tabular}

To find whether there are any differences among the subjects of the study sample in the social intelligence level and it dimensions according to the home place variable, the means and stand deviation where collected in addition to finding the known differences the $\mathrm{T}$ test was conducted which the Table 5 shows. 


\section{Ml Macrothink}

Journal of Studies in Education

ISSN 2162-6952

2019, Vol. 9, No. 3

Table 5. The results of the $\mathrm{T}$ test for the level of social intelligence and it dimensions in the light home place variable.

\begin{tabular}{lllllll}
\hline $\begin{array}{l}\text { Social } \\
\text { Intelligence }\end{array}$ & $\begin{array}{l}\text { Home } \\
\text { place }\end{array}$ & Mean & $\begin{array}{l}\text { Std } \\
\text { Deviation }\end{array}$ & T & df & Sig \\
\hline Communicate & City & 3.165 & .355 & .803 & 187 & .423 \\
with others & Vallije & 3.121 & .334 & & & \\
Social & City & 3.177 & .335 & .481 & 187 & .631 \\
Interaction & Vallije & 3.152 & .297 & & & \\
Respond to & City & 3.145 & .260 & 1.198 & 187 & .232 \\
others & Vallije & 3.085 & .331 & & & \\
Influence and & City & 3.266 & .334 & .143 & 187 & .887 \\
Influence in & Vallije & 3.273 & .335 & & & \\
social & & & & & & \\
attitudes & & & & & & \\
Total & City & 3.190 & .205 & .979 & 187 & .329 \\
& Vallije & 3.161 & .175 & & & \\
\hline
\end{tabular}

To find whether there are any differences among the subjects of the study sample in the social intelligence level and its dimensions according to the student work variable, the means and stand deviation where collected in addition to finding the known differences the $\mathrm{T}$ test was conducted which the Table 6 shows.

Table 6. The results of the $\mathrm{T}$ test for the level of social intelligence and it dimensions in the light student work variable.

\begin{tabular}{lllllll}
\hline $\begin{array}{l}\text { Social } \\
\text { Intelligence }\end{array}$ & Employment & Mean & $\begin{array}{l}\text { Std } \\
\text { Deviation }\end{array}$ & T & df & Sig \\
\hline Communicate & Work & 3.191 & .333 & 2.377 & 187 & .018 \\
with others & Not work & 3.191 & .338 & & & \\
Social & Work & 3.175 & .309 & .695 & 187 & .488 \\
Interaction & Not work & 3.144 & .308 & & & \\
Respond to & Work & 3.098 & .321 & .204 & 187 & .838 \\
others & Not work & 3.107 & .305 & & & \\
Influence and & Work & 3.193 & .324 & 3.296 & 187 & .001 \\
Influence in & Not work & 3.350 & .327 & & & \\
social & & & & & & \\
attitudes & & & & & & \\
Total & Work & 3.166 & .175 & .322 & 187 & .748 \\
& Not work & 3.174 & .195 & & & \\
\hline
\end{tabular}

To find the correlation between social intelligence and social relationship student's cooperation and competition Pearson correlation coefficient was conducted which the Table 7 shows. 
Table 7. Correlation between the social intelligence level and its dimensions and relationship student's cooperation and competition.

\begin{tabular}{llllll}
\hline $\begin{array}{l}\text { Social } \\
\text { relationship }\end{array}$ & $\begin{array}{l}\text { Communicate } \\
\text { with others }\end{array}$ & $\begin{array}{l}\text { Social } \\
\text { Interaction }\end{array}$ & $\begin{array}{l}\text { Respond to } \\
\text { others }\end{array}$ & $\begin{array}{l}\text { Influence } \\
\text { and }\end{array}$ & $\begin{array}{l}\text { Social } \\
\text { Intelligence }\end{array}$ \\
\hline & & & $\begin{array}{l}\text { Influence in } \\
\text { social } \\
\text { attitudes }\end{array}$ & \\
Cooperation & $.296^{* *}$ & $.202^{* *}$ & .074 & .095 & $.187^{* *}$ \\
Competitive & $.150^{*}$ & .042 & .018 & .156 & .000 \\
\hline
\end{tabular}

\section{The results discussion}

The results indicated that the level of social intelligence of the individuals' sample was average, and that is as a result to the nature of the used strategies in educational situations that is based on feeding the students the data, of which does not help the student in initiating social interaction between the teacher and the student, as well the methods of social upbringing of our culture and environment that is based on the instructions of the family and not on the interaction and participation between the family individuals, therefore it effects the social intelligence and its dimensions. And the results of this study were agreed with the study (Samee, 2007).

The question is whether there is any differences between the sample individuals in the pattern of the social relationships (cooperation, competition) according to the accommodation of the student (city or village), the results pointed out that the differences are not statistically indicated, and that could be as a result of the Jordanian environment which is ruled by habits and tradition, whether in the city or the village, where the environment encourages cooperation between others and participating with their different occasions, and helping them in completing some tasks, but it indicates that the individual has an interest in competition through their comparisons with the others. And the results of this study were the differed with what he pointed out the results indicate that there is a low level of cooperate behaviour with a similar rise in competitive behaviour levels of village and city citizens. (Garcia, Rivera, Greenfield, 2015).

The question is whether there are any differences of statistical indications in the pattern of social relationships (cooperation, competition) according to the variable of student's employment. The results indicated that there are differences of statistical indication between the sample individuals in competition and cooperation, and the employed students have interests in cooperation higher than the unemployed students. And that the unemployed students have a tendency competition and comparing themselves with others, where this result could be explained as the employed student is used to cooperate with others in completing a lot of missions at work, whereas the unemployed student is used to the individual work and observing others and their performance.

The question is whether there are any differences in the level of social intelligence and residence in city or country. The results indicated that the differences between the residents 
of the city and country is not statistical function. That could be as a result to the social upbringing method that our society is bound to whether in the village or city. The learning and teaching strategies that are used by the teacher in educational situations are similar, with no statistical indication to any differences. And the results of this study were agreed with the study (Malik, Siddique, Hussain, 2018).

The question is there any differences in the levels of social intelligence according to the variable of student's employment the results indicate that the differences in levels of social intelligence between employed and unemployed students are not statistically indicated. But the dimensions of social intelligence are indicated in the dimension of interacting with others. The differences of statistical indication is for the employed students, and that could be as a result of the experiences in interacting with others that the employed students have experienced, by the experience that they have won from work their competence in this dimension increased. And the statistical differences in the effecting and affecting in social situations are for the unemployed students. And that could be as a result that the unemployed students have more spare time to use in social communicating and interacting with others and affecting them, mimicking many forms therefore these forms could be used in affecting others.

The question is there any relationship between the level of social intelligence and dimension with the pattern of social relationships (competition and cooperating). The results indicated that the cooperating pattern is positively connected with interacting with others dimension, as with social intelligence as a whole. When the cooperating increases the social intelligence of the individual. Whereas the competition pattern is with inverse relationship between it and interacting with others, where the competition decreases when interacting with others. And that could be as a result of cooperating focuses on the group's needs and interacting with them because social intelligence is a set of skills of which lets the individual deal with social situations, whereas competition justifies this relationship as comparing with others therefore it could raise hate and hatred between them and individual thinking plus self-dependence in processing situations.. And the results of this study were agreed with the study (Won, Heo, and Choi 2018). The results indicated that there is a positive relationship between emotional and social intelligence and flexibility.

\section{Recommendations}

- Interest in preparing programs that help in contributing in increasing the level of social intelligence of students.

- Recommending in reconsidering the strategies that the teachers use in educating situations where the focus is on strategies that encourage cooperating.

- Conducting a unique set of studies to know the relationship between social intelligence with other variables. 


\section{References}

Abu Amsha, Ibrahim. (2013). Social Intelligence and Emotional Intelligence and Their Relationship to Sense of Happiness among the University Students in the Governorate of Gaza. Master Theses, Gaza.

Albrecht, Karl. (2006). Social Intelligence the New Science of Success. Jossey Bass, USA.

Ali, asghar, Ahmad lqbal\& Khan Adnan. (2019). Gender, Age and Locality Based Social Intelligence differences of B.Ed. (Hons) students. Global Social Sciences Review GSSR, 17(1), 207-213. https://doi.org/10.31703/gssr.2019(IV-I).19

AL-Kfaween,Etaf. (1994). Forms of Social Relationship Which Finds Among The Classroom Group, And Its Relation With Achievement Level, That Belong To a Sample Of Students From The First Primary Class in The Great Amman Area. Jordan, Master Theses. Jordan University, Jordan.

Amomani, Abedel - Latif\&Atoum, Adnan. (2016). Cultural Intelligence among Jordanian University Students. International Journal of Education \& Management, 6(1), 48-53.

Andrew,Ahlgren \& Johnson, David,W. (1979). Sex Differences In Cooperative And Competitive Attitudes From The 2n Through The $12^{\text {th }}$ Grads. American Psychological Association, 15(1), 45-49. https://doi.org/10.1037//0012-1649.15.2.45

Aghode, Vishal. (2014). Emotional and social intelligence competence: Implications for Instruction. International journal of pedagogies and learning, 8(2), 66-77. https://doi.org/10.1037//0012-1649.15.2.45

Baggiyan N \& Pankajam R. (2017). Social Intelligence Relation to Academic achievement. International journal of Research grant Hal ayah Acknowledge Repository, 5(3), 18-22.

Bjorkgvist, Kaj. Osterman, Karin \& Kaukiainen, Ari. (2000). Social intelligence -empathy= aggression. Aggression and Violent behavior, 5(2), 191-200. https://doi.org/10.1016/S1359-1789(98)00029-9

Bondnar, Alexander \& Bodnar, Elvira. (2018). Relationship between social intelligence Level and Accentuations of Adolescents Character. The Fifth International Luria Memorial Congress «Lurian Approach in International Psychological Science» Knowledge E Publishing, UAE 1-9.

Buzdar, Muhammad, Ayub. Wagas, Muhammad \& Mhonsin, Muhammad, Naeem. Nadeem, Muhammad. (2016). Relationship Between Social intelligence And Religious Orientation of University Students. Journal of Educational Research, 19(1), 1-9.

Cantor, Nancy \& Kihlstrom, John. f. (2000). Social Intelligence, The Cognitive Basis of Personality.

Ebrahimpoor, Habib. Zahed, Adel \& Elyasi Azim. (2013). The study of Relationship between Social intelligence and organizational performance Case study: Ardabil Regional water 
company's Managers. International of journal organization Leadership, 2(1), 1-10. https://doi.org/10.33844/ijol.2013.60352

Eshghi, Parto., Etemadi, Maryam.,Mardani, Manizhe., Fanaei, Enieh., \&Hosaini, Taghi, Agha. (2013).Social Intelligence and its SubScales among Physical education expertise in Isfahan education organizations study of gender differences. European journal of experimental Biology, 3(4), 13-17.

Ganaie, M, y. M., \& Mudasir, Hafiz. (2015). A study of Social intelligence\& Academic Achievement of College Students of District Srinagar, J\&K, India. Journal of American Science, 11(3), 23-27.

-Garcia, Camilo. Rivera, Natanael, \& Greenfield, Patricia. (2015). The Decline of Cooperation, The Rise of Competition Developmental Effects of Long - term Social Change in Mexico. International journal of psychology, 50(1), 6-11. https://doi.org/10.1002/ijop.12120

Gnanadevan, R. (2011). Social intelligence Of Higher Secondary Students In Relation To Their Socio economic Stats. Mier journal of Education Studies Trends and Practices, 1(1), 60-66.

Goleman, Daniel. (2006). The socially intelligent educational Leadership, 76-81.

Hooda, Deepti. Sharma, Nov Rattan, \&Yadava Amrita. (2009). Social intelligence as Predictor of Positive Psycho local Health. Journal of the Indian Academy of Appalled Psychology, 35(1), 143-150.

Humphrey, Barbara. Johnson Roger T\& Johnson, David, W. (1982). Effects Of Cooperative, Competitive And Individualistic Learning On Students Achievement In Science Class. Journal of Research Science Teaching, 19(5), 60-66. https://doi.org/10.1002/tea.3660190503

-Hut, T. (2019). The measurement of social intelligence. American psychological Association, 12(3), 317334. https://doi.org/10.1037/h0075832

Kolawole, E, B. (2008). Effect of Competitive and Cooperative Learning Strategies on Academic Performance of Nigerian Students in Mathematics. Educational Research and Review, 3(1), 33-37.

Lau, Jennifer. (2016). Social intelligence and the next generation. Kings college London and NCS.1-40.

Malik, Mushtag Ahmad, Siddique, Faisal, \& Hussain Syed Nasir. (2018). Exploring The Development Of Social intelligence Of Students During University Years. Pakistan journal of Education, 35(1), 45-58.

Qin, Zhining. Johnson David W., \& Johnson Roger T. (1995). Cooperative Versus Competitive Efforts and Problem Solving. Review of Educational Research, 65(2), 129-143. https://doi.org/10.3102/00346543065002129 
-Reiter, Palmon Roni, \& Rickers Jon, D. (2001). Selfreported Leadership Experiences in Relation To inventoried Social and Emotional intelligence. Current Psychology Developmental Learning Personality Social, 20(2), 154-163. https://doi.org/10.1007/s12144-001-1023-2

Rezaei, Akbar. Khosroshahi \& Bahadori Jafar. (2018). Optimism, Social intelligence And Positive Affect As predictors Of University Students Life Satisfaction. European Journal Mental Health, 13(2), 150-162. https://doi.org/10.5708/EJMH.13.2018.2.3

Roseth, C.J, Johnson \& D,W, Johnson,R T. (2008). Promoting Early Adolescents Achievement And Peer Relation ship The Effect of Cooperative,Competitive And Individualistic Goal Structures. Psychological Bulletin, 134(2), 223-246. https://doi.org/10.1037/0033-2909.134.2.223

Saxena, Sumanlata, \& Jain, Rajat, Kumar. (2013). Social intelligence Of Undergraduate Students for In Relation To Their Gender and Subject stream. Journal of Research \& Method in Education, 1(1), 1-4. https://doi.org/10.9790/7388-0110104

Sameer, Babu, M. (2007). Social Intelligence and Aggression among Senior Secondary School Students. ERIC. ED 500484, 1-30.

-Terwase, Joyoce, M., Ibaishwa, Reuben \& Enemari, Joy. (2016). Parenting Styles and Gender as Predictors of Social Intelligence among Adolescents in Idoma Land. Mediterranean Journal of Social Science, 7(1), 181-187. https://doi.org/10.5901/mjss.2016.v7n1s1p181

Tone, Erin B., Nahmias, Eddy, \& Baxeman, Roger. (2018). Social Anxiety and Social Behavior: Attest of Predictions from an Evolutionary. Clinical Psychological Science. 7(1), 110-129. https://doi.org/10.1177/2167702618794923

Vyrost, J., \& Kyselova, M. (2006). Personality Correlates of Social intelligence. Studia Psychology, 48(3), 207-212.

Weis, Susanne. (2008). Theory and measurement of social intelligence as cognitive performance construct. PhDThesis, University KoblenzLondau, Germany.

-Wyer, J R Roberts \& Srul Thomas, k. (1989). Social intelligence and Cognitive Assessments of Personality. Lawrence Erlbaum Associates Publishers. New Jersey.

Won, Sun-Jin., Heo, ChungUK, \& Choi, Young -Soon. (2018). The Effect of School Life Emotional Intelligence and Social Intelligence on Resilience of Nursing University Students. Biomedical Research, 29(2), 3829-3834. 